ODP Science Services

ODP Technical Note 36

\title{
SHIPBOARD SCIENTISTS HANDBOOK ${ }^{1,2}$
}

\author{
ODP Science Services ${ }^{3}$
}

\section{INTRODUCTION \\ Ocean Drilling Program}

The Ocean Drilling Program (ODP) is an international partnership of scientists and governments that have joined together to explore Earth's structure and history beneath the ocean basins. The central purpose of ODP is to provide (1) core samples and downhole measurements from beneath the oceans' floors and (2) facilities to study those samples. During each cruise, specific scientific objectives are pursued by the personnel on board the research vessel the JOIDES Resolution. Data generated by ODP lead to a better understanding of the processes of plate tectonics, the Earth's crustal structure and composition, conditions in ancient oceans, and changes in climate through time and, in turn, to a fuller comprehension of the evolution of our planet.

\section{Deep Sea Drilling Project}

ODP's predecessor, the Deep Sea Drilling Project (DSDP), was established in 1966 at Scripps Institution of Oceanography, University of California, San Diego (USA), to acquire deep-sea cores on a routine basis for scientific study. Using the drilling vessel Glomar Challenger, DSDP obtained $>60 \mathrm{mi}$ of core from $>1000$ holes at 624 sites around the world. DSDP developed techniques for computer-controlled dynamic positioning to stabilize the ship over a borehole in mid-ocean and for reentry systems that allow drill bits to be changed and reinserted into the drill hole.
${ }^{1}$ ODP Science Services, 2006. Shipboard scientists handbook. ODP Tech. Note, 36 [Online]. Available from World Wide Web: <http://wwwodp.tamu.edu/publications/tnotes/ tn36/INDEX.HTM>. [Cited YYYY-MMDD]

${ }^{2}$ See Disclaimer, p. 29.

${ }^{3}$ Ocean Drilling Program, 1000

Discovery Drive, College Station TX

77845-9547, USA. 
Joint Oceanographic Institutions, Inc.

ODP is managed by the Joint Oceanographic Institutions (JOI), Inc., under contract with the U.S. National Science Foundation (NSF). JOI is a consortium of 20 major U.S. oceanographic institutions, which provide management support to scientific research programs of international stature. The institutions involved are Columbia University (Lamont-Doherty Earth Observatory), Florida State University, Oregon State University (College of Oceanic and Atmospheric Sciences), Pennsylvania State University (College of Earth and Mineral Sciences), Rutgers, The State University of New Jersey (Institute of Marine and Coastal Sciences and Faculty of Arts and Sciences), Stanford University (School of Earth Sciences), Texas A\&M University (College of Geosciences), University of California at San Diego (Scripps Institution of Oceanography), University of Florida, University of Hawaii (School of Ocean and Earth Science and Technology), University of Miami (Rosenstiel School of Marine and Atmospheric Science), University of Michigan (College of Literature, Science, and the Arts), University of Rhode Island (Graduate School of Oceanography), University of South Florida (College of Marine Science), University of Texas at Austin (Institute for Geophysics), University of Washington (College of Ocean and Fishery Sciences), and Woods Hole Oceanographic Institution.

\section{JOIDES}

The Joint Oceanographic Institutions for Deep Earth Sampling (JOIDES) advises JOI in the overall objectives of ODP. JOIDES is an international group of scientists that provides planning and program advice regarding science goals and objectives, facilities, scientific personnel, and operating procedures. The primary governing arm of the JOIDES organization is the Executive Committee (EXCOM). The Science Committee (SCICOM) evaluates advice from the science advisory structure, prioritizes scientific objectives, and ranks drilling programs, forwarding recommendations on scientific objectives and drilling plans to EXCOM for final approval. The science advisory structure is headed by SCICOM and consists of two Science Steering and Evaluations Panels (Environmental and Interior) and the Operations Committee (OPCOM) along with short-lived detailed planning groups that are created as needed to assist in translating broad thematic programs into concrete drilling plans. Three service panels (Pollution Prevention and Safety [PPSP], Site Survey [SSP], and Scientific Measurements [SciMP]) and a Technology and Engineering Development Committee (TEDCOM) report to OPCOM.

\section{Funding}

Funding for ODP is provided by the following agencies: Australia/ Canada/Chinese Taipei/Korea Consortium for Ocean Drilling; Deutsche Forschungsgemeinschaft (Federal Republic of Germany); Institut National des Sciences de l'Univers-Centre National de la Recherche Scientifique (INSU-CNRS; France); University of Tokyo (Ocean Research Institute; Japan); National Science Foundation (United States); Natural Environment Research Council (United Kingdom); European Science Foundation Consortium for Ocean Drilling (Belgium, Denmark, Finland, Iceland, Ireland, Italy, The Netherlands, Norway, Portugal, Spain, Sweden, and Switzerland); and the Marine High-Technology Bureau of 
the State Science and Technology Commission of the People's Republic of China.

\section{Science Operator}

As Science Operator for the Ocean Drilling Program, Texas A\&M University (ODP/TAMU) has leased the drillship JOIDES Resolution to continue the ocean exploration begun aboard the Glomar Challenger during DSDP. Operation of the drillship is managed from facilities at ODP/ TAMU in College Station, Texas.

TAMU is responsible for the following:

1. Implementing science planning and operations;

2. Guiding engineering development and improvement of drilling technology;

3. Selecting scientists for the shipboard scientific parties;

4. Designing, furnishing, and maintaining shipboard and shorebased laboratories to meet the needs of the shipboard scientific staff;

5. Curating and distributing all core samples and data;

6. Publishing scientific results; and

7. Providing public information about ODP.

\section{Repositories}

ODP/TAMU is curator of all ODP cores in four repository facilities. The Bremen Repository, located at the University of Bremen (Germany), stores ODP cores from the Atlantic, Arctic, and Antarctic Oceans and the Mediterranean and Caribbean Seas. Cores from the Pacific and Indian Oceans and the Red Sea are housed at the Gulf Coast Repository at TAMU in College Station, Texas (USA). DSDP cores from the Pacific and Indian Oceans and the Red Sea are stored at the West Coast Repository at Scripps Institution of Oceanography, University of California, San Diego, California (USA). DSDP cores from the Atlantic, Arctic, and Antarctic Oceans and the Mediterranean and Caribbean Seas are stored at the East Coast Repository at Lamont-Doherty Earth Observatory, Columbia University, Palisades, New York (USA).

\section{SCIENTIST PRECRUISE PREPARATIONS}

\section{Physical}

Each shipboard scientist must obtain a physical examination by a duly licensed physician. ODP mails all pertinent forms along with instructions to participants 4 months in advance of each cruise. The completed physical examination form must be returned to ODP 2 months in advance of the cruise port call to allow sufficient time for review by the ship's physician. To board the ship, each participant must have a completed physical examination form on file at ODP/TAMU.

Shipboard participants who have experienced motion sickness are advised to discuss precautionary measures with their doctor. Medications are available on board to prevent seasickness but are less helpful after symptoms have begun. Also, it is advisable to notify the ship's 
doctor as soon as possible at the beginning of the cruise that seasickness may be a concern.

\section{Prescriptions}

Shipboard participants requiring special or prescription medicines must bring an ample 2-month supply for their use. Prescriptions cannot be refilled on board, and only small quantities of over-the-counter drugs are maintained.

\section{Passport/Visas}

Before the cruise, each shipboard participant must obtain a passport and the necessary visas and inoculations required by the countries to be visited. The JOIDES Resolution is a Liberian registered vessel; therefore, it is necessary for all U.S. personnel to have valid U.S. passports in their possession upon joining or leaving the vessel at American ports as well as during international travel to and from the ship.

Each scientist is responsible for having the correct tourist or transit visas. Visa requirements may differ if arriving/departing by ship vs. airplane; participants must verify these requirements with the appropriate consulate or embassy. On rare occasions, special visas are required. If travel to or from the ship includes personal travel time, the visa requirements may differ; participants must verify these requirements with the appropriate consulate or embassy.

\section{Travel Arrangements}

\section{From Institutions Outside the United States}

Scientists from countries other than the United States must make their own travel arrangements, both for the cruise and for postcruise meetings. Travel costs for non-U.S. scientists are paid by funding sources within their own countries.

\section{From Institutions Inside the United States}

For U.S. scientists from academic institutions and government agencies, travel to and from the cruise and postcruise meetings is arranged by ODP/TAMU and paid by funds available through the U.S. Science Support Program (USSSP). Questions about travel arrangements may be addressed to the ODP/TAMU Travel Supervisor, Ocean Drilling Program, 1000 Discovery Drive, College Station, Texas 77845-9547, or via e-mail to Denise DeShetler at deshetler@odpemail.tamu.edu.

\section{Scientific Prospectus}

The Scientific Prospectus presents scientific and operational program details for each leg. It is the main reference for prospective leg participants and potential shore-based investigators. The prospectus also represents the contract between the Co-Chief Scientists, ODP, and the JOIDES community.

The Prospectus is placed on the Web $\sim 2$ months after the precruise meeting (this time frame is highly dependent on how complete the document is at the end of the precruise meeting) at wwwodp.tamu.edu/publications/SCIPROSP.HTML. 
Sample Requests

Sample requests will be reviewed by the Staff Scientist and Curator 23 months before the cruise. Copies of sample requests will be sent to the Co-Chief Scientists 1-2 months before the cruise begins. The Sample Request Form may be accessed at www-odp.tamu.edu/curation/ subsfrm.htm.

The Sample Distribution, Data Distribution, and Publications Policy may be accessed from the Curation Web page at www-odp.tamu.edu/ publications/policy.html.

\section{Computer Environment}

ODP maintains an open multiplatform environment (i.e., Windows, Mac, UNIX, and DOS). Participants who have special computing/platform needs or are planning to bring equipment and/or software aboard the ship must contact the ODP/TAMU Staff Scientist at least 1 month before the cruise. For detailed information on computers, software, and support availability on the ship see www-odp.tamu.edu/isg/.

\section{Special Laboratory Needs}

Scientists should alert ODP as early as possible if special equipment, supplies, laboratory space, and so on are needed. A list of supplies generally available on board the ship is posted on the ODP Web page.

\section{Shipping Supplies and Equipment}

All luggage, including official ODP hand-carried items and personal effects, is subject to inspection by Customs.

\section{Shipping from ODP}

Supplies/equipment for each leg are staged at ODP/TAMU, and then packed/shipped from ODP via surface and/or air freight to the port call. Special research equipment can be sent to ODP/TAMU to the attention of the Staff Scientist for the leg. If these items are received by posted cut-off dates they will be included in the ODP/TAMU shipments. Documentation is required for items sent for trans-shipment to generate proper shipping papers. Information accompanying equipment/supplies for shipment should include (1) individual item description, (2) serial/model numbers, (3) quantity, (4) value (USD), (5) dimensions/ weights, and (6) PO numbers (if applicable).

\section{Shipping Directly to Port}

Items intended for the ship should be sent directly to our port agent only in exceptional circumstances. Such direct shipments must be preapproved and coordinated with the ODP/TAMU logistics office. Direct shipments will be opened for inspection prior to loading on the ship. Note that by law the Ship Captain has the authority to refuse to load any substance considered hazardous to health or safety. 
ODP SCIENCE SERVICES

\section{On-Loading Freight}

Freight sent to port is loaded beginning on day 2 of the port call. Clearances, crew changes, and information exchanges known as "crossovers" take place on day 1 .

\section{Off-Loading Freight}

Freight from a port call is off-loaded as soon as possible after clearances have been granted.

\section{Ship's Stores}

A ship's store operated by the ship crew sells miscellaneous personal supplies and toiletries. The store is small, so supplies should be brought from home or bought at port call. A store run by ODP sells ODP/TAMU T-shirts and sweatshirts, JOIDES Resolution baseball caps, small cloth ODP patches, ODP coffee mugs, and JOIDES Resolution postcards.

\section{Money}

ODP accepts U.S. currency and credit cards for e-mail and ship's stores; however, phone calls must be paid with U.S. currency (cash or traveler's checks). ODP does not accept foreign currency or personal checks.

\section{Dietary Issues}

Special dietary requirements should be brought to the Staff Scientist's attention as early as possible prior to the leg.

The following items may not be brought on board the ship as they are strictly prohibited: firearms, alcohol, or illegal drugs. See the "Appendix: ODP/TAMU Administrative Information and Shipboard Policies."

\section{Things ODP Does Supply}

- Safety glasses (not prescription)

- Hard hats: required outside aft of the accommodations area and at all life boat drills. See "Shipboard Policies and Safety" in the Appendix.

- Work gloves

- Hearing protection (when necessary)

- Limited cold-weather gear (only for high-latitude legs)

- Laundry bags and service

- Linens and towels (beds are tended and sheets changed by the Catermar crew)

- A collection of paperback books and various magazines

- A selection of movies 


\section{Checklist of Items to Bring to the Ship}

Table T1 lists items that should be brought to the ship. Shopping is usually available close to the hotel/ship for many of the items; however this is not always true.

\section{SCIENTIST CRUISE INFORMATION}

\section{Port Call}

\section{Scientists Arrival}

Scientists are usually scheduled to arrive at the departure port on the day 2 of the port call; thus, a hotel room is not needed. Co-Chief Scientists are usually scheduled to meet the ship when it docks to cross-over with the previous leg Co-Chief Scientists. Scientists will be provided with information on how to contact the ODP/TAMU Logistics Coordinator at his hotel at port, or the port agent's office, to learn the ship's location. If any major delays are encountered when traveling to the port call, scientists should promptly notify the Logistics Coordinator at his hotel at port or, if he is not available for some reason, contact Denise DeShetler at ODP Travel (979-845-3205), Pat Thompson at Material Services (979-845-2113), or the designated port agent by telephone or telex.

\section{Check-In}

Scientists should check in with the Yeoperson when boarding the ship. The Yeoperson collects passport information and provides information regarding room assignments, life on the ship, and any ongoing events (e.g., meetings).

\section{Room Assignments}

Room assignments are posted by the Laboratory Officer upon arrival at the ship. Cabin assignments are made by the Laboratory Officer and Staff Scientist. Scientists normally move into their cabins immediately upon arrival at the ship. Changes in berthing must be cleared through the Laboratory Officer.

\section{Safety Information}

Before starting work in the shipboard laboratories, scientists must confirm that they have reviewed the material safety data sheets (MSDS) for the hazardous materials in the laboratory and are familiar with the necessary procedures for handling these materials safely. If not familiar with the MSDS used in the U.S., there is a set of these available on the ship and ODP/TAMU will provide appropriate training.

\section{Safety Meeting}

The Captain and Staff Scientist will hold an orientation/safety meeting before the ship sails.
T1. Items to bring to the ship, p. 30. 


\section{Science Meeting}

A second orientation meeting for the shipboard scientific staff is held on board as well, usually before the ship sails. This meeting serves to introduce the scientists to the ship and to discuss the leg objectives, shipboard sampling programs, and arrangement of shipboard work schedules (including scientists' shifts at the sampling table).

\section{Under Way to the First Site}

\section{Personnel List}

Shortly after the ship leaves port, the Yeoperson sends a list of all scientific and technical crew members to ODP/TAMU.

\section{Sampling Plan}

Within $24 \mathrm{hr}$ after sailing, the Curatorial Representative sends a complete cruise sampling plan to ODP/TAMU that has been approved by the Co-Chief Scientists and includes the fate of all submitted sample requests.

\section{First Transit}

While in transit from the departure port to the first site, scientists have time to familiarize themselves with laboratory equipment and standard ODP/TAMU data collection entry policies. The ODP/TAMU Staff Scientist and technical personnel devote much of their effort during the transit to helping scientists with this task.

If the transit time to the first site is more than a couple of days, there is often time to set up an informal seminar series, during which shipboard scientists can present talks on their research interests to other members of the shipboard staff. A $35-\mathrm{mm}$ carousel slide projector, transparency projector, computer overhead projector for PowerPoint presentations, and a microphone are available in the conference room on the 7th level of the labstack.

\section{Sailing Personnel}

\section{Co-Chief Scientists}

Each cruise has two Co-Chief Scientists, who represent the JOIDES community in the shipboard leadership team (with the Leg Project Manager/Staff Scientist, the Operations Manager, the Laboratory Officer, and the Curator) in coordinating the shipboard science activities toward attaining cruise objectives set by the JOIDES scientific and operational committees.

\section{Leg Project Manager/Staff Scientist}

The Leg Project Manager/Staff Scientist is the ODP/TAMU representative responsible for ensuring the successful implementation and completion of the cruise-based science plan as defined by the JOIDES panels. The Staff Scientist coordinates the scientific activities before, during, and shortly after the cruise; works with the Curator to develop and implement a curatorial plan for the cruise; assists with precruise 
and cruise operational planning; and works with the Co-Chief Scientists to prepare and edit cruise reports and publications.

\section{Scientists}

During each cruise, specific scientific objectives are pursued by the personnel on board. The complement of $\sim 25$ scientists works as a team on routine core studies in addition to performing special sampling and analytical projects within their own fields.

\section{Operations Manager}

The Operations Manager is the official representative of ODP/TAMU responsible for seeing that the SCICOM drilling and logging guidelines are followed during cruise planning and cruise operations. During the cruise, the Operations Manager coordinates the execution and modification (as required) of the leg operations plan with the rest of the shipboard leadership team, drilling contractor, and logging contractor personnel. For information about drilling services and tools see wwwodp.tamu.edu/dsd.

\section{Technical Support/Laboratory Officer}

About 20 technicians and other ODP personnel provide technical support for shipboard data collection and operational procedures and assist in upgrading and maintaining the shipboard laboratories, computers, and scientific equipment. For more information about the laboratories and technical support see www-odp.tamu.edu/sciops. The ODP/TAMU technical support group is under supervision of the Laboratory Officer (LO) and the Assistant Laboratory Officer (ALO), who are part of the shipboard leadership team.

\section{Logging Operations}

Personnel from Lamont-Doherty Earth Observatory (LDEO) Borehole Research Group (BRG) manage wireline logging operations to obtain electronic measurements in ODP drill holes. For more information on logging services and tools see www.ldeo.columbia.edu/BRG/ brg_home.html.

\section{Ships Crew}

Ocean Drilling Limited (ODL) is contracted to supply a drillship to carry out the drilling program at sea. The registered ship name is the research vessel JOIDES Resolution. The ship's crew of 52 consists of those personnel engaged in the drilling operations and running of the ship and those who provide cleaning, laundry, and galley service (Catermar) on the ship.

\section{Shipboard Scientists' Responsibilities}

\section{Overview}

Each scientist participating in an ODP cruise has a number of general responsibilities, as summarized here, and a specific job assignment, which is addressed in the following section. 


\section{Cruise Objectives}

Each participant is expected to familiarize himself/herself with the scientific objectives and operational strategies of the leg as outlined in the leg Scientific Prospectus.

\section{Precruise Sample Request}

Each participant is required to submit a sample request 3 months before the cruise with an outline of proposed postcruise research. This request/proposal will be used to allocate core samples and coordinate postcruise research.

\section{Safety Information}

Before starting work in the shipboard laboratories, each scientist must confirm that they have reviewed the MSDS for the hazardous materials in the laboratory and are familiar with the necessary procedures for handling these materials safely.

\section{Data Collection}

Shipboard scientists working as a team collect, analyze, and compile data conforming to ODP procedures and format established for each laboratory station and job description. Work shifts are usually $12 \mathrm{hr}$ per 24-hr day. All data collected during a cruise are the property of the entire shipboard party for $1 \mathrm{yr}$ (moratorium period) and then become public.

\section{Reports}

Shipboard scientists produce scientific reports in the form of site chapters for the Initial Reports (IR) volume and present their findings to the other participants in shipboard science meetings. They also assist the Co-Chief Scientists in writing summary reports such as the Weekly Report, Site Summary Report, and the Preliminary Report for the IR. Authorship of cruise reports is collective, individuals contribute according to their job assignment and scientific expertise.

- Weekly Report: a brief report that covers operations and science conducted during the previous week, written by the Co-Chief Scientists and the Staff Scientist and sent each week to ODP/TAMU while at sea.

- Site Summary Report: written by the Co-Chief Scientists assisted by the Staff Scientist at the end of each site, these reports contain a summary of operations conducted at the site provided by the Operations Manager and of the science as reported by the team of scientists.

- Preliminary Report: presents a summary of the operational and scientific cruise results. It is the only cruise report available to the general scientific community until the Initial Reports volume is published $1 \mathrm{yr}$ after the cruise. The Preliminary Report also satisfies contractual obligations with JOI, NSF, and the U.S. State Department. The Preliminary Report is placed on the World Wide Web 2 months after the cruise, when the document is complete at the end of the cruise. 
- Initial Reports: the IR volume is the first volume in the two-part set (along with the Scientific Results [SR] volume) called the Proceedings of the Ocean Drilling Program. Both volumes are primarily intended to be used as reference texts. The IR is a record of the scientific and operational results from an ODP leg. Together with the ODP database and the cores recovered, it presents the immediate legacy of each ODP leg.

\section{Sampling}

Scientists are assigned core sampling shifts during the cruise, typically $2 \mathrm{hr}$ out of each 12-hr shift for a soft rock leg. When a core is ready for sampling, the assigned sampling shift takes all the samples designated for shipboard sampling by the Sample Allocation Committee (SAC), under guidance of the Curatorial Technician. Leg participants are also strongly encouraged to take part in postcruise sampling parties, if travel funding is available.

\section{Cruise Evaluations}

At the end of the cruise, all shipboard scientists are encouraged to complete cruise evaluations. These evaluations guide ODP in upgrading laboratory equipment and procedures and in improving life on board ship.

\section{Scientific Publications}

Shipboard scientists first serve the overall leg objectives. After the cruise, they are responsible for analyzing their samples as proposed in their sample request and/or cruise application and for reporting the results in the SR volume of the ODP Proceedings or in an appropriate scientific journal (see the ODP Publications Policy at wwwodp.tamu.edu/publications/policy.html).

\section{Shipboard Scientists' Job Descriptions}

\section{Overview}

Scientific participants are invited to perform particular jobs that need to be completed to ensure the success of the cruise. An individual's scientific expertise is taken into account as much as possible during job assignments. There may not always be a one-to-one relationship between an individual's expertise and objectives and the required job. In such a case, shipboard scientists should be aware that they first serve the overall leg objectives as outlined in the Scientific Prospectus in the most effective way possible prior to auxiliary science. For more detailed information on shipboard laboratories, see www-odp.tamu.edu/sciops/ labs.html.

\section{Core Describers}

Core describers may have expertise in a wide variety of fields including sedimentology, petrography, petrology, or structural geology. The optimal mix of expertise is determined by the leg objectives and the individuals selected by the Co-Chief Scientists, the Manager of Science Services, and the Staff Scientist. Core description may involve the following tasks: 
- Macroscopic visual description of split cores, entered in the core description database to generate "barrel sheets" (soft sediments) or in more detailed core section graphic templates (igneous rocks);

- Microscopic observations from smear slides and/or thin sections, entered to word processing files, and, in some cases, added to the macroscopic description forms;

- Acquisition of physical properties data with the split-core track, including diffuse color reflectance, magnetic susceptibility, and digital images (these may be done by physical properties specialist);

- Preliminary interpretation of depositional, diagenetic, magnetic, or deformational processes;

- Selection of samples, in consultation with other scientists, for carbonate, X-ray diffraction (XRD), or inductively coupled plasma (ICP) analysis, and thin sections.

- Analysis of XRD and/or ICP data, if the appropriate expertise exists (otherwise it is not prudent to collect these data on the ship; XRD/ ICP analyses may also be done by the geochemistry specialist).

\section{Stratigraphic Correlator}

Stratigraphic correlators are key positions on legs where complete stratigraphic sections (achieved by coring multiple holes at a site) are an essential component of the leg objectives. Completion of a meters composite depth (mcd) depth scale in near real time guides coring operations and ensures complete stratigraphic coverage. For maximum efficiency, two correlators are needed to cover a 24-hr period and to guarantee feedback within $1 \mathrm{hr}$. Correlation is achieved using a Sun workstation and the customized program Splicer. Precruise training is required for correlators inexperienced in Splicer software. The job typically also includes operation of the multisensor track because the main data sets used for core correlation are magnetic susceptibility, natural gamma radiation, and gamma ray attenuation density from whole-core logging. Other data may be needed to improve correlation such as color reflectance logs, macroscopic descriptions from split cores, or biostratigraphic information.

\section{Biostratigrapher}

Shipboard micropaleontologists provide age data and an age/depth model for each site. This is done using (1) core catcher samples as soon as possible after a core is recovered and (2) additional samples, up to one per section, in at least one hole per site. For nannofossils and, sometimes, diatoms, toothpick samples may be taken from the open ends of core sections on the catwalk. For other microfossil groups, samples in addition to the core catchers have to be taken from the split core working halves. Some stratigraphic boundaries may be analyzed in more detail on board ship using samples taken from the split workinghalf cores. Full assemblage analysis is not necessary on board ship; rather, identification of useful microfossil datums for constructing age/ depth plots and sedimentation/accumulation rate curves is the primary emphasis. Microfossil datums are also used for integration with multisensor track data for core/core correlation and construction of spliced composite sections. Paleoenvironmental or bathymetric data, principally from benthic foraminifers, may also be of primary importance on certain legs. 
Shipboard micropaleontologists process their own samples and have a fully equipped processing laboratory with two acid hoods for this purpose. A variety of slides, mounting media, and maceration chemicals are available for all major microfossil groups.

A reference library with texts, journals, and reprints is available to help shipboard paleontologists identify microfossils. Because of limited shipboard space, this library is not comprehensive and micropaleontologists should check with ODP before their leg to see what references are available. Micropaleontologists are advised to bring their own set of references to supplement the shipboard library. A computer image database of nannofossils is also available in the paleontology laboratory.

Micropaleontology Reference Collections (MRCs) are available at a number of institutions worldwide. These contain reference slides of planktonic foraminifers, diatoms, calcareous nannofossils, and radiolarians from DSDP and ODP cores. Scientists may visit these collections to view material before sailing. Check the MRC Web page for information: www-odp.tamu.edu/mrc/mrcpage.HTML.

\section{Magnetostratigrapher}

Paleomagnetists conduct or supervise paleomagnetic measurements and reduction of paleomagnetic data to intensities and direction of magnetization. Paleomagnetists also provide absolute orientation data for deformational structures measured in the core, if appropriate. Some additional rock magnetic properties can be acquired on the ship, which is particularly useful if the magnetic properties are (partly) ephemeral (e.g., postrecovery dissolution, reduction, or oxidation of magnetic minerals). For detailed information, see ODP Technical Note 18 at wwwodp.tamu.edu/publications/tnotes/tn18/f_pal.htm.

\section{Physical Properties Specialist}

Scientists assigned to physical properties specialist usually determine the following properties: moisture content and grain density on core samples, $P$-wave velocity on split cores and/or core samples, thermal conductivity on full cores or split cores, if appropriate, and vane shear strength on split cores, if appropriate. In addition, these scientists oversee and document the overall physical property measurement program in consultation with other scientists, including the full-core and splitcore logging systems. They also ensure that calibrations and control measurements are carried out according to protocol to ensure data quality control. For detailed information, see the physical properties handbook (ODP Technical Note 26) at www-odp.tamu.edu/publications/ tnotes/tn26/TOC.HTM.

\section{Geochemist}

Organic chemists monitor cores for hydrocarbon content. They advise the Operations Manager, Leg Project Manager, and Co-Chief Scientists when hydrocarbon levels in cores may constitute a potential safety or pollution hazard.

Inorganic geochemists conduct elemental analysis on interstitial water and/or solid sediment or rock samples and provide preliminary interpretations. For detailed information, see ODP Technical Note 15 at www-odp.tamu.edu/publications/tnotes/tn15/f_chem1.htm. ODP Marine Laboratory Specialists assist in geochemical analyses. 


\section{Downhole Logging, Geophysics Specialist}

The downhole logging/geophysics specialist advises the Co-Chief Scientists on the logging program for the cruise; works closely with the LDEO Logging Staff Scientist in designing, implementing, and interpreting the logging program; and assists the Schlumberger Field Engineer with data acquisition, if required. This position often includes responsibility for other geophysical tasks such as acquisition, analysis, and presentation of downhole temperature measurements; seismic data acquisition and presentation (site surveys); and construction of synthetic seismic profiles.

\section{Microbiologist}

Major responsibilities of shipboard microbiologist include the following:

- Conduct onsite contamination tests by adding highly sensitive tracers (i.e., perfluorocarbons and fluorescent microspheres) to the drilling fluids and the core barrel to evaluate the potential extent of contamination of the cores by the drilling process.

- Conduct sampling for shipboard and shore-based microbiological analyses.

- Conduct elemental analysis on interstitial water and/or sediment to provide preliminary interpretations of microbial activity.

- Make thin sections of sediment and/or rock for preliminary interpretations on contamination and bacterial activity.

- Start cultures and incubation of samples collected using different media.

ODP Marine Laboratory Specialists assist in microbiology sampling and analyses. For more information on contamination tests and sampling protocol, see ODP Technical Note 28 at www-odp.tamu.edu/publications/tnotes/tn28/INDEX.HTM.

\section{Other}

On rare occasions, specialists may sail to perform more specialized measurements, which may include packer experiments, installation of CORKs, or vertical seismic profiling.

\section{JOIDES Resolution}

\section{Online Ship Tour}

An online brochure guides you through the Ocean Drilling Program's research vessel, JOIDES Resolution, at www-odp.tamu.edu/public/onboard.html.

\section{Vessel}

The JOIDES Resolution is a flush deck-type drillship with a forecastle (fo'c'sle) and poop deck. It is a dynamically positioned (DP) ship with a length of $470 \mathrm{ft}(143 \mathrm{~m})$, beam of $70 \mathrm{ft}(21 \mathrm{~m})$, and draft of $27.6 \mathrm{ft}(8.4$ $\mathrm{m})$. The displacement of the ship is 16,596 long tons. On site, she can suspend as much as $30,000 \mathrm{ft}(9150 \mathrm{~m})$ of drill pipe and maintain her 
position in up to $27,000 \mathrm{ft}(8200 \mathrm{~m})$ of water. The drillship can operate in air temperatures of $-18^{\circ}$ to $43^{\circ} \mathrm{C}$ and sea temperatures of $-2^{\circ}$ to $27^{\circ} \mathrm{C}$. Crew accommodations and navigation facilities are located forward; electrical generation, propulsion machinery, and a heliport are located aft. Subdivision of the hull is provided by nine major transverse bulkheads, two longitudinal wing bulkheads, and an inner bottom. Special features of her design particularly valuable for deep-ocean drilling include dynamic positioning equipment with a computerized control system and satellite navigation equipment.

\section{Days at Sea}

The JOIDES Resolution is a completely self-sustained unit carrying sufficient fuel, water, and stores to enable her to remain working at sea for 70 days without replenishing. Emergency reserves for an additional 35 days are carried on board.

\section{Moonpool}

A $22-\mathrm{ft}(7 \mathrm{~m})$ diameter well, the moonpool, is located on centerline amidships to provide an area for running drilling equipment to the seafloor.

\section{Thrusters}

Thruster wells are located on centerline forward, on the forward port side, and on the aft starboard side of the vessel, as well as in the ship's skeg. The drilling and thruster wells are free-flooding.

\section{Power}

Drilling, propulsion, and positioning equipment is diesel-electric powered.

\section{Speed}

Twin propellers give the JOIDES Resolution an average cruising speed of $11 \mathrm{kt}$.

\section{Ship Capabilities}

- $30,000 \mathrm{ft}(9000 \mathrm{~m})$ drill string

- Stable drilling platform

- Large enclosed storage areas for drill pipe and casing

- Drawworks with 31,000 ft (9448 m) of wireline

- Berths for 51 scientific and technical personnel

- 13,400 sq ft (1245 sq m) of laboratory and office space

- Strengthened hull for drilling in high-latitude waters.

\section{Dynamic Positioning System}

JOIDES Resolution's dynamic positioning system employs an acoustic referencing device to maintain the ship over a specific location while drilling in water depths of up to $27,000 \mathrm{ft}(8200 \mathrm{~m})$. The positioning system uses 10 retractable thrusters occupying forward, port, and star- 
board wells and two fixed thrusters in the skeg, each capable of 22,600 lb $(100,525 \mathrm{~N})$ of thrust. When operating in conjunction with the ship's main screws, the thrusters enable her to move in any direction. Four hydrophones are mounted within the hull and continually receive signals transmitted from a sonar beacon placed on the ocean floor. The signals are fed into a computer that calculates the position of the ship relative to the beacon based on the delay times of the arriving signals. The computer automatically controls the thrusters and main propulsion unit to maintain the ship's heading and location over the hole. The dynamic positioning system has both computerized and manual controls. Under normal operating conditions, the system can safely maintain the drillship at a desired surface location within $1 \%$ of water depth.

\section{Shipboard Facilities}

\section{Overview}

Offices, laboratory facilities, and living spaces on the ship are heated, air conditioned, and acoustically insulated. Hot and cold potable water, nonpotable circulation water, salt water, and cooling water are available as required. Power throughout the labstack is either 120 or $208 \mathrm{~V}$, threephase, 60 cycle. Circuits are available in each laboratory for both ship's power and regulated power. Regulated power by definition is not uninterruptible power but power in which the output voltage is kept within certain limits and voltage spikes are truncated.

\section{Cabins}

A variety of two- and four-person cabins with corresponding lavatory (four people share one lavatory facility) and shower facilities are provided for shipboard scientists and technicians. Of the 51 berths assigned to scientific and technical personnel, 32 are in four-person rooms. The rooms are heated/air conditioned and are cleaned by the ship's stewards. The JOIDES Resolution has an excellent freshwater storage system that allows all personnel to shower daily. Fresh towels and bed linens are provided regularly. Personal decorations may be added to the rooms but must be removed at the end of the cruise; rooms are not to be permanently modified in any way. Many of the cabins do not have windows, so a lighted watch or a small flashlight can be helpful. Clothing and belongings can be stored in a drawer under the bed and a locker. There is usually a small desk and chair in the cabin as well. Curtains around each bunk can be drawn to provide privacy, and there is a small light at the head of the bunk. Electric outlets are $110 \mathrm{~V}, 60$ cycle.

Because the ship runs $24 \mathrm{hr}$ a day, cabins are usually shared with someone who is on a different shift; thus, there is usually someone sleeping in the cabin at any time. It is helpful to bring a backpack to carry items needed during the day to avoid returning to the cabin.

\section{Conference Room}

A conference room is available for meetings and science presentations. 


\section{Copy Machines}

Two photocopiers are available onboard ship. Because of limited supplies, personal copying must be kept to a minimum. The ODP Electronics Technicians repair these machines.

\section{Gymnasium}

The gym is located in one of the storage holds and is not air conditioned. There are three adjustable-tension exercise bicycles; a treadmill; two flywheel-resistance rowing machines; and a three-station weight machine with a bench press, upper and lower pulleys, leg extension/leg curl bench, and abdominal board; a squat press; two stairmasters; a full set of free-weights; exercise mats; and a punching/speed bag. The gym has an audio-video system (with aerobics videotapes) and a ping-pong table.

\section{Hospital}

The ship's hospital is located on the fo'c'sle deck just inside the starboard door to the quarters. The hospital is staffed by a certified medical doctor (MD) whose regular office hours are posted at the beginning of each cruise. The doctor is on call $24 \mathrm{hr}$.

The hospital has two beds plus a triage table/bed, sleeping quarters for the doctor, and its own lavatory and shower facilities. It has an Xray machine, defibrillator, and artificial respirator apparatus in addition to medicines, bandages, and other first-aid supplies. The hospital has limited medicines; participants should bring adequate supplies of needed prescriptions. The ship is not equipped to handle complications due to allergy shots, so the doctor does not give allergy shots. For questions about medicines, please contact the leg Staff Scientist.

Shipboard participants who have experienced motion sickness, or have reason to believe it may be a problem, are advised to discuss precautionary measures with their doctor before the cruise. Medications are available to prevent seasickness but are less helpful after symptoms have begun. Also, it is advisable to notify the ship's doctor as soon as possible at the beginning of the cruise that seasickness may be a concern.

\section{Labstack}

Laboratory and data collection facilities are housed in a separate structure installed aft of the main superstructure and forward of the rig floor. The "labstack" contains seven levels: four above deck and three below deck in the casing hold. An elevator connects all levels of the laboratory structure and is used primarily for transportation of cores and supplies. The topmost level contains the downhole measurements laboratory, thin section laboratory, and a conference room. The next level down, the bridge deck, contains the core entry and core splitting areas of the core laboratory as well as the sedimentology, paleomagnetism, and physical properties laboratories. Below is the fo'c'sle deck with chemistry, X-ray diffraction, microbiology, paleontology preparation, and microscope laboratories. The main deck houses shipboard computer facilities, the science lounge, the Yeoperson's office, and the Curatorial Representative's office. 
Below deck are three more laboratory levels. On the upper 'tween deck are the electronics shop, the photography laboratory, and a storage area for laboratory supplies. The lower 'tween deck has the second look laboratory, refrigerated core storage, and more storage for laboratory supplies. The hold deck has more refrigerated core storage and laboratory supplies storage. Additional information about the shipboard laboratories can be found at www-odp.tamu.edu/sciops/labs.html.

\section{Computer Environment}

ODP maintains an open multiplatform environment (i.e., Windows, Mac, UNIX, and DOS). Special computing/platform needs should be discussed with the ODP/TAMU leg Staff Scientist.

\section{Library}

The science library is located forward on the fo'c'sle deck of the ship's superstructure. PC and Mac computers are located in the library. Funding for the library is limited; questions about available resources should be directed to the leg Staff Scientist.

\section{Laundry}

The ship provides free laundry service, and because of this service it is not necessary to bring many changes of work clothes. However, since it takes equal time to launder a small amount as a large amount of clothes, it is requested that laundry be accumulated for a few days before sending it out to be washed. Soiled clothes placed in the bags provided are to be left in front of the cabin doors. Laundry is picked up daily and returned the same day.

\section{Mess Hall}

The mess hall is on the ship's upper 'tween deck. It is open throughout the day and night, except for $1 \mathrm{hr}$ before and after each meal to allow time for cleaning and setup. Meals are served cafeteria style. The capacity of the mess hall is 40 persons, with no predetermined seating arrangement. It is expected that everyone wear clean clothes to meals, with the exception of on-duty drilling crew members. Cereal, milk, coffee, tea, bread, and sandwich fillings are always available.

\section{Meals}

Meals are prepared by a subcontrator Portuguese company called Catermar. Comments from previous cruise evaluations indicate that the staff are extremely helpful and are interested in doing their best to make meals a pleasant experience. They are usually quite willing to accommodate to the best of their ability special food requests. Breakfast usually consists of typical food choices such as eggs, sausage, cereal, fruit, oatmeal, etc. They usually do not serve more typical lunch or dinner foods; if other items are needed talk to the camp boss.

There are usually three choices of entrees, starches, and vegetables at lunch, supper, and the second shift midday meals. Unfortunately, the second shift midday meal is not always to the excellence of the noon and supper meals and the 6:00 a.m. meal only provides breakfast food when it is the dinner meal for the second shift. However, they will cook a hamburger at the 6:00 a.m. meal upon request. 
A salad bar with fresh vegetables is available as long as the vegetables last. After 8 weeks at sea, the choice of fresh vegetables may diminish. The cooks make wonderful pastries and breads and have quite a selection of desserts. Soft drinks, juice, milk, and fresh yogurt are available in the cooler in the mess hall.

Individual tastes are highly subjective, and it is not an easy task to provide a large, diverse, multicultural group of people with foods that everyone likes. Vegetarians may find choices are limited.

\section{Special Foods}

Special food needs (e.g., soy milk, tofu, etc.) should be sent to the Staff Scientist 4 months prior to the cruise; ODP will try to accommodate these requests if possible. It is often cheaper and easier to find special food items in the U.S. and ship them to the port call; thus, as much lead time as possible should be provided.

\section{Meal Hours}

Breakfast: 0500-0700 hr

Lunch: $1100-1300 \mathrm{hr}$

Supper: $1700-1900 \mathrm{hr}$

2nd shift midday: 2300-0100 hr

\section{Offices}

The Operations Manager and the Laboratory Officer have offices on the ship's bridge deck, and the Co-Chief Scientists and the Staff Scientist share office space next to the Laboratory Officer's office. The main deck houses the Yeoperson's and Curatorial Representative's offices.

\section{Science Lounge}

The science lounge contains audio-video equipment in designated viewing and reading areas. Video equipment includes a DVD player, a VHS player, a laser disk player, 25-in and 19-in color monitors, a 50-in movie screen, and a $16-\mathrm{mm}$ movie projector. Videotapes are provided by the ship operator. Slide projectors, an overhead projector, and a screen are also available. An electronic keyboard is kept in the science lounge. It has headphones, so a keyboardist can enjoy making music without disturbing others. A selection of paperbacks and magazines is kept in the lounge for leisure reading; more are located in the science library. Various games are available on the ship's network.

\section{Ship's Intercom}

In every laboratory there is an intercom system near each phone. One person can call another by paging over the intercom system and then conversing by phone. There are dedicated voice-powered phone lines from the bridge to the engine room and rig floor for use by the ship's crew. 
Shipboard Communications

\section{Proprietary Information}

Communications to colleagues or family (verbal or written) must not contain scientific results from the cruise. These should appear in a form authored by the entire shipboard scientific party.

\section{E-mail}

\section{General}

Procedural details and instruction on the use of the GroupWise email system will be given at the beginning of the cruise. E-mail on board and between ship and shore is available to every cruise participant through software available on both Macs and PCs. Each participant is assigned an account before ship's departure. Regular ship-toshore communications are halted at the end of the cruise during crew change while messages from the previous cruise are archived.

\section{Cost}

A maximum of $500 \mathrm{~KB}$ can be sent and received at no charge. Thereafter, e-mail is billed at the rate of $\$ 3.30 / 100 \mathrm{~KB}$ sent. This price is subject to revision at the beginning of each cruise. Periodic updates as to account statuses will be posted on the ship during the cruise. All users will receive an invoice for usage beyond the 500-KB allowance at the end of the leg. Payment for usage above $500 \mathrm{~KB}$ is expected in USD or credit card at the end of cruise to the Yeoperson. Messages sent or received cannot be larger than $20 \mathrm{~KB}$ (may decrease) each.

Files $>20 \mathrm{~KB}$

A filter on the e-mail system allows transfer to the ship only files that are $<20 \mathrm{~KB}$. Larger files are rejected and the sender receives a notice that their message exceeded the allowable size.

If it is absolutely necessary to send a large file, the filter can be opened by the system Manager (contact ODP/TAMU Help Desk at 979845-7918). There is no size filter on outgoing mail from the ship, so message size should be checked carefully before sending.

\section{Shipboard Scientists' E-mail Address}

- JRS_lastname@odpemail.tamu.edu

- Example:JRS_doe@odpemail.tamu.edu

Underscores are only for Internet access-not for internal e-mail messages.

\section{Questions}

Questions about shipboard communications should be directed to the staff scientist.

\section{Direct Voice Communication}

MARISAT calls can be made worldwide collect or paid for in USD (cash or traveler's checks only) before the end of the cruise. The charge for these MARISAT calls is $\sim \$ 3 / \mathrm{min}$ for voice/fax call with a 3-min minimum. However, credit card calls can be placed from the library's telephone at $\$ 2.85 / \mathrm{min}$ for Zone 1 through IDB provider set-up. Prices are subject to change. 
End-of-Cruise Port Call Mail

The shipboard addressee will receive regular postal mail sent to the following address at the end of the cruise when the ship arrives in port.

(Name of Shipboard Participant)

c/o Science Services - A155

Ocean Drilling Program

1000 Discovery Drive

College Station, TX 77845-9547

\section{SCIENTIST END OF CRUISE AND POSTCRUISE INFORMATION}

\section{Samples and Personal Items}

\section{Cruise Sampling Plan}

As coring operations are completed at a site, the Co-Chief Scientists, Staff Scientist, and Curator (SAC) prepare a final sampling plan based on original and revised sample requests. The shipboard Curatorial Representative is responsible for preparing a complete cruise sampling plan at the end of the leg.

\section{Shipping Samples/Data/Equipment}

ODP technicians will assist in shipping items home. Detailed information will be provided near the end of the cruise.

For all shipments, complete addresses are required and post office boxes cannot be used. The recipient must ensure that correct phone numbers and the name of a contact person are provided to the ODP staff preparing the shipment and that the contact person will be available on the receiving end, since express courier shipments often arrive at the destination before the returning scientist.

\section{Shipping Outside the United States}

Samples/personal items sent to non-U.S. destinations are normally dispatched via express courier service. It is important to provide the name of the international airport and the airport code that is located near the shipping address. Note that the recipient is responsible for clearing items through customs in the destination country. Shipments bound for destinations outside the U.S. will be sent via freight importer in the destination country, which minimizes potential problems and delays (critical for some samples), if non-U.S. participants can provide the name of the freight importer customarily used by their home institution.

\section{Shipments to United States Destinations}

Shipments sent to U.S. destinations may be sent via air freight or surface freight, depending on the transit times. It is important to provide complete contact information to the ODP staff preparing the shipment. Additional information may be requested if required. Shipments from foreign ports to U.S. addresses will be sent via ODP/TAMU's agent in Texas and then forwarded to their final destination. 
Special Shipments

ODP should be advised of shipments requiring special handling (e.g., refrigerated, or frozen samples) as early as possible, if possible even before the beginning of the leg. In the case of shipments requiring special handling it is especially important that correct phone numbers and the name of a contact person are provided to the ODP staff preparing the shipment and that the contact person be available on the receiving end. Shipments requiring special handling are sent to all destinations via express courier services (DHL, Federal Express, Airborne, etc.).

\section{Personal Box/Data Box}

U.S. participants may send one "personal box" from the ship with the regular ODP/TAMU freight. The box can contain only work clothes, boots, books, toiletries, or similar low-value, nonvital items. Please do not include food, as an insecticide is added to the shipping container. The maximum size box allowed is 12 in $\times 18$ in $\times 6$ in. Every personal box sent from the ship to the U.S. must be accompanied by a completed U.S. Customs form 3299 (available on board); the form requires, among other information, exact departure and return flight information of the sender. If changes in return scheduling occur, it is the responsibility of the owner to notify ODP Material Services (979-8455780 ) and supply the correct information immediately upon return to the U.S.

\section{Postcruise Scientific Publications}

\section{Obligation to Publish}

All shipboard and shore-based participants who receive ODP samples or data during the first 12 months postcruise are required to submit one of the following: a manuscript to the Scientific Results volume for the leg or a manuscript related to leg objectives or to a related discipline to an internationally recognized peer-reviewed scientific journal that publishes in English. See the ODP Sample Distribution, Data Distribution, and Publications Policy at www-odp.tamu.edu/publications/policy.html.

\section{Scientific Results}

A Scientific Results volume is a collection of peer-reviewed papers presenting results of postcruise research relating to the aspects of scientific drilling from a leg. Publication of results in this volume fulfills the individual's obligation for participating in the cruise. An SR volume may contain regular scientific papers, data reports, and/or synthesis papers. The SR volume is distributed $\sim 4$ yr after the cruise. Scientific Results volumes are published electronically on CD-ROM and World Wide Web formats and are no longer printed on paper.

\section{ODP/TAMU CONTACT NAMES AND NUMBERS}

Table T2 lists key ODP/TAMU staff who interact with participating scientists (this is not a comprehensive list of all ODP/TAMU personnel). In general, the Staff Scientist assigned to the leg will be the primary

T2. Key personnel contact information, p. 31. 
ODP SCIENCE SERVICES

ODP TECHNICAL NOTE 36

ODP/TAMU contact. Table T3 lists Web sites that may be useful for cruise planning.

T3. ODP related web addresses,

p. 32. 


\section{APPENDIX: ODP/TAMU ADMINISTRATIVE INFORMATION AND SHIPBOARD POLICIES}

\section{ODP/TAMU Administration Information}

\section{Operations Deviations from the Scientific Prospectus}

Changes to the operational strategy presented in the Scientific Prospectus require approval. This is primarily for safety considerations and pertains mainly to relocating a site, operating in a new site not previously identified, or drilling deeper than previously approved. These requests should be forwarded to Jack Baldauf, Deputy Director of Science Operations at TAMU. If Jack is not available, contact Tom Davies, Manager of Science Services (see the list of ODP/TAMU contact names and numbers in Table T2). Approval must also be obtained before deviating from the clearance approved document. Any changes to the Scientific Prospectus can be only effected with the approval of the SCICOM and/ or the Safety Panel through communication with ODP management.

\section{Drug-Free Workplace/Alcohol Policy}

\section{Drug-Free Workplace Act}

Federal contractors and grant recipients are required to maintain drug-free workplaces by adhering to certain requirements. The act specifically prohibits the "unlawful manufacture, distribution, dispensation, possession, or use of a controlled substance" in the workplace.

\section{Compliance}

Failure to comply could result in the loss of government funding and/or impoundment of the ship.

\section{Transocean/ODP Endorsement}

This policy, as well as the prohibition of alcoholic beverages and firearms, is fully endorsed by the Ocean Drilling Program and Transocean because it contributes to safety throughout the ship. Policies that enhance the safety of operations at sea and of the participating personnel are non-negotiable.

\section{Distribution}

These policies are posted on board the vessel, common knowledge to those who routinely sail on the ship, and distributed in the package of briefing material that is provided to all shipboard scientists.

\section{Additional Information}

The Staff Scientist or Kim Johnson with IODP Human Resources can answer questions on this policy (johnson@iodp.tamu.edu).

\section{Texas A\&M Harassment Statement}

\section{Overview}

The employment and educational environment throughout the Texas A\&M University System shall be free from all forms of sexual discrimination and sexual harassment. Conduct constituting sexual harassment is specifically prohibited and will result in appropriate sanctions. Sexual harassment, as defined below, is a Class A misdemeanor under Texas Law, and is directly applicable to activities on this vessel. 
Definition

Sexual harassment means unwelcome sexual advances; requests for sexual favors; or other verbal, visual, or physical conduct of a sexual nature, submission to which is made a condition of a person's exercise or enjoyment of any right, privilege, power, or immunity, either explicitly or implicitly.

\section{Examples}

In relation to the foregoing, sexual harassment may range from unthinking and often unintentional verbal denigration of a person on the basis of gender to actual physical assault. Some examples that may constitute sexual harassment include offensive sexual flirtations, advances, or pressure for sexual activity; unwanted touching, pinching, or unnecessary brushes; unwanted exposure to sexual graffiti, photographs, or suggestive objects; sexual innuendoes or statements made at inappropriate times or disguised as humor, or obscene gestures; disparaging remarks about one's gender; or any offensive or abusive physical contact.

\section{Procedures}

To deal promptly and fairly with charges of sexual harassment and to protect the and dignity of all individuals involved, each Texas A\&M University System component will establish and give wide publicity to a rule for filing a complaint. Such rules shall facilitate and encourage reporting, and shall assure timely investigation, resolution, and appropriate sanctions against persons found to have violated this policy. Complainants should know that the reporting of allegations of sexual harassment is a very serious matter and that steps will be taken to resolve complaints.

\section{Retaliation}

Retaliatory action of any kind is prohibited when taken against a witness or other person providing testimony, or against the complainant seeking redress under the applicable rules dealing with sexual harassment. Such retaliatory action shall be regarded as a separate and distinct cause for complaint.

\section{Contact}

If you believe that sexual harassment has occurred or it has been brought to your attention, please contact the Staff Scientist, Operations Manager, and/or Kim Johnson with ODP Human Resources at johnson@odpemail.tamu.edu.

\section{Shipboard Policies and Safety}

\section{Alcohol}

Use of alcoholic beverages or controlled substances is forbidden. In 1988 the U.S. Government enacted the Drug-Free Workplace Act, which contains a requirement for federal contractors and grant recipients to maintain drug-free workplaces by adhering to certain requirements. The act specifically prohibits the "unlawful manufacture, distribution, dispensation, possession, or use of a controlled substance" in the workplace. Workplace is defined as all areas of the vessel. Failure to comply with this law may result in loss of government funding. Accordingly, ODP relies upon the integrity, professional attitude, and good judgment of all cruise participants to refrain from engaging in these types of activities. 


\section{Compassionate Emergencies}

It is the policy of the ODP not to interrupt or alter the course of a cruise for the purpose of evacuating an ODP employee or a cruise participant in the event of a personal emergency on shore. Personal emergencies include but are not limited to a death in the family or the serious illness of a family member. Exceptions to this policy may be made at the discretion of the ODP/TAMU Director or Deputy Director. An exception would be based in part on the location of the ship, availability of resources for evacuation, and the nature of the emergency.

\section{Derrick}

Personnel are prohibited from going aloft in the derrick because of safety issues.

\section{Drills}

The scientific work of the JOIDES Resolution takes her to areas where immediate assistance is unavailable. Thus, it is necessary to rely upon the knowledge and experience of the ship's crew to avoid potentially dangerous situations. This is done in a systematic way developed through the practice of weekly drills. These drills are required by law, and the ship takes pride in the serious manner in which they are organized and executed. Fire drills, man overboard drills, and abandon ship drills are held at least once weekly; attendance is mandatory. Helicopter emergency drills are held less frequently. Procedures and details connected with these drills are explained at the first drill, held a few hr out of port.

\section{Hard Hats}

Hard hats and safety glasses must be worn by all ODP and Transocean personnel when outside on catwalks, rig floor, or aft decks (on the way to the helipad or underway geophysics laboratory, for example).

\section{Firearms}

Firearms or other weapons cannot be transported or possessed.

\section{Fires}

Discovery of a fire or a similar dangerous situation should be reported to the bridge immediately. Do not try to combat the fire, but stand by to aid or point out the area involved to the Emergency Squad as they arrive. If the participant judges that using an extinguisher on a fire at its inception might help, this may be done only after notification of the bridge. After the Emergency Squad has taken control, participants should report to their assigned emergency station.

\section{Halon}

The shipboard computer facility is protected by a Halon fire extinguisher system, located in the Koomey room on the upper 'tween deck. This system protects the computer machine room, System Manager's office, and computer user's area. Only the Captain may authorize manual 
activation of the Halon system in the event of a fire. A loud alarm sounds, and protected areas must be evacuated immediately and all doors tightly closed. Halon is nontoxic but it must be contained within the air-tight protected area to be effective. As in all emergency situations, the bridge must be notified immediately.

\title{
Lifeboats
}

The JOIDES Resolution is equipped with four motor-propelled, selfcontained, totally enclosed lifeboats, each with a capacity of 56 persons. The boats contain oxygen breathing systems to be used when operating in a fire area. There is also a complete exterior water-spray system to prevent buildup of excessive interior temperatures. Lifeboats are located above the bridge deck, two each on port and starboard. They are launched and boarded from the fo'c'sle deck. In addition to the lifeboats, the ship has inflatable life rafts.

\section{Lifeboat Assignments}

Lifeboat assignments and emergency signals are posted in passageways and personnel stations. This information must be thoroughly and carefully read; the Chief Mate or Captain can answer any questions.

\section{Life Jackets}

Life jackets are worn during every boat drill by all persons. Regulation-type life jackets are kept aboard for all personnel. They are stored in each cabin and near each lifeboat. Immersion suits are also stored in each cabin and in the labstack.

\begin{abstract}
Alarms
Personnel not directly involved in dealing with an emergency are to report to their assigned stations immediately upon hearing an alarm. This facilitates assignment of additional help or directing abandon-ship procedures. Depending on the severity of an emergency, the Captain may call upon any or all hands aboard for assistance; therefore, everyone must be ready to respond to any order the Captain or ship's officers may issue in a drill or real emergency.
\end{abstract}

\section{Types of Alarms}

There are different emergency alarms to signify unsafe conditions aboard ship:

- General Emergencies: For a general emergency, such as a fire or collision, the general alarm and ship's whistle sound for at least $10 \mathrm{~s}$ and instructions describing the type of emergency and location are given over the public address system.

- Abandon Ship: For abandon-ship circumstances, six short blasts followed by one long blast are given on the alarm and whistle. One short blast means to lower boats; two short blasts means to stop lowering boats. Accompanying commands and instructions to abandon ship are given over the public address system.

- Man Overboard: If a person falls overboard, an alarm is given by hailing "Man Overboard" and notifying the mate on duty. Three long blasts on the whistle may be given. 
- Return to Safe Conditions: When an emergency is over, the "All Clear" signal for dismissal is given by three short blasts of the whistle and general alarm.

\section{Rig Floor}

In the interest of preventing accidents, it is requested that while on site all persons not directly connected with drilling operations stay off the rig floor. For those who are not familiar with the machinery and its operation or who do not take proper precaution, crossing the rig floor while pipe operations are in progress can be extremely hazardous. The driller and his team are operating equipment that handles loads of over 300 tons under dynamic conditions and that is unforgiving of error. The driller is responsible for the safety of everyone on the rig floor; a lapse in concentration on the driller's part could easily result in a serious or fatal accident to a visitor or crew member. It could also cause a "wreck" with disastrous consequences to the equipment, drill string, or even the voyage.

The following guidelines must be observed:

- Hard hat and safety glasses are required outside the deck house and labstack areas; safety shoes are required on the rig floor and around machinery or moving loads.

- The drill floor must be avoided during pipe handling operations unless there is specific business there; walk behind the drawworks as an alternative to crossing the drill floor. Visiting or otherwise distracting the driller while he is operating machinery is forbidden.

- Passage between the iron roughneck or the dual elevator system and the centerwell and on the piperacker catwalk without specific reason is discouraged; participant must be fully aware of the current operational situation.

- Participants should be constantly alert for men working aloft in the derrick and for crane loads being swung overhead, and must not stand underneath!

- The rig floor may not be used as a route of convenience to the underway geophysics or logging winch areas.

\section{Smoking}

Smoking is permitted only in nondangerous areas and is never allowed where "No Smoking" signs are posted. Smoking is permitted in the living quarters only where signs are posted stating it is a "designated smoking area." 


\title{
PUBLISHER'S NOTES
}

Material in this publication may be copied without restraint for library, abstract service, educational, or personal research purposes; however, this source should be appropriately acknowledged.

Pimmel, A., and Claypool, G., 2001. Introduction to shipboard organic geochemistry on the JOIDES Resolution. ODP Tech. Note, 30 [Online]. Available from World Wide Web: <http://www-odp.tamu.edu/publications/tnotes/tn30/INDEX.HTM>. [Cited YYYY-MM-DD]

Distribution: Electronic copies of this publication may be obtained from the ODP Publications homepage on the World Wide Web at http://www-odp.tamu.edu/publications.

This publication was prepared by the Ocean Drilling Program, Texas A\&M University, as an account of work performed under the international Ocean Drilling Program, which is managed by Joint Oceanographic Institutions, Inc., under contract with the National Science Foundation. Funding for the program is provided by the following agencies:

\author{
Australia/Canada/Chinese Taipei/Korea Consortium for Ocean Drilling \\ Deutsche Forschungsgemeinschaft (Federal Republic of Germany) \\ European Science Foundation Consortium for Ocean Drilling (Belgium, Denmark, Finland, Iceland, \\ Ireland, Italy, The Netherlands, Norway, Portugal, Spain, Sweden, and Switzerland) \\ Institut National des Sciences de l'Univers-Centre National de la Recherche Scientifique (INSU-CNRS; \\ France) \\ Marine High-Technology Bureau of the State Science and Technology Commission of the People's \\ Republic of China \\ Ocean Research Institute of the University of Tokyo (Japan) \\ National Science Foundation (United States) \\ Natural Environment Research Council (United Kingdom)
}

\section{DISCLAIMER}

Any opinions, findings, and conclusions or recommendations expressed in this publication are those of the author(s) and do not necessarily reflect the views of the National Science Foundation, the participating agencies, Joint Oceanographic Institutions, Inc., Texas A\&M University, or Texas A\&M Research Foundation. 
ODP SCIENCE SERVICES

ODP TECHNICAL NOTE 36

Table T1. Items to bring to the ship.

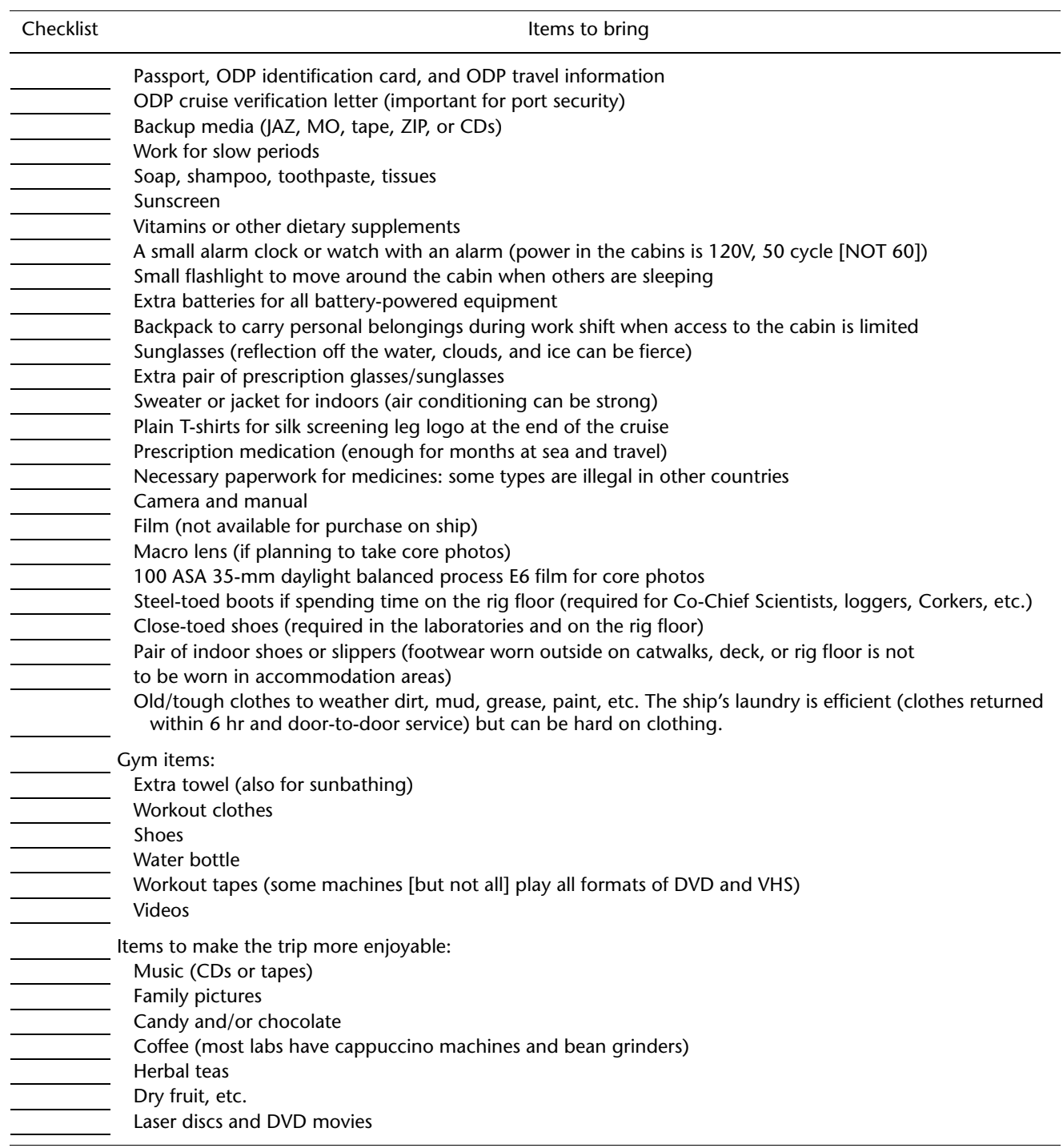


Table T2. ODP/TAMU contact names and numbers.

\begin{tabular}{|c|c|c|c|c|}
\hline Title & Name & e-mail address & Phone number & Comments \\
\hline \multicolumn{5}{|l|}{ Headquarters: } \\
\hline Director & Jeff Fox & fox@iodp.tamu.edu & (979) $845-8480$ & \\
\hline Deputy Director of Science Services & Jack Baldauf & baldauf@iodp.tamu.edu & (979) 845-9297 & \\
\hline Deputy Director of Data Services & Ann Klaus & annklaus@iodp.tamu.edu & (979) $845-2729$ & \\
\hline \multicolumn{5}{|l|}{ Science Services: } \\
\hline Manager & Mitch Malone & malone@iodp.tamu.edu & (979) 845-5218 & \\
\hline \multirow[t]{3}{*}{ Staff Scientists } & Adam Klaus & aklaus@iodp.tamu.edu & (979) 845-3055 & \\
\hline & Carlos Alvarez Zarikian & zarikian@iodp.tamu.edu & (979) 845-2522 & \\
\hline & Cédric John & john@iodp.tamu.edu & (979) $845-2480$ & \\
\hline Curator & John Firth & firth@iodp.tamu.edu & (979) 845-0507 & Fax number: (979) 845-0876 \\
\hline Supervisor of Technical Support & Brad Julson & julson@iodp.tamu.edu & (979) 845-5716 & \\
\hline \multirow[t]{3}{*}{ Laboratory Officers } & Burney Hamlin & hamlin@iodp.tamu.edu & (979) 845-2496 & \\
\hline & Bill Mills & mills@iodp.tamu.edu & (979) $845-2478$ & \\
\hline & Roy Davis & davis@iodp.tamu.edu & (979) 845-3602 & \\
\hline Supervisor of Operational Support & Mike Storms & storms@iodp.tamu.edu & (979) 845-2101 & \\
\hline Supervisor of Materials Support & Pat Thompson & thompson@iodp.tamu.edu & (979) 845-2113 & \\
\hline Administrative Assistant & Janice Muston & muston@iodp.tamu.edu & (979) 845-7209 & Additional: (979) 845-3602 \\
\hline \multicolumn{5}{|l|}{ Tools and Analytical Services: } \\
\hline Manager & Jay Miller & miller@iodp.tamu.edu & (979) 845-2197 & \\
\hline Supervisor of Analytical Services & Peter Blum & blum@iodp.tamu.edu & (979) 845-9299 & \\
\hline Supervisor of Engineering Services & Derryl Schroeder & schroeder@iodp.tamu.edu & (979) 845-8481 & \\
\hline Administrative Assistant & Marti Kacer & kacer@iodp.tamu.edu & (979) 845-2056 & \\
\hline Staff Researcher & Karen Graber & graber@iodp.tamu.edu & (979) $845-7924$ & Cruise evaluations \\
\hline \multicolumn{5}{|l|}{ Administration and Personnel: } \\
\hline Personnel Assistant & Ollie Berka & berka@iodp.tamu.edu & (979) $845-2583$ & Physical examination and general administrative policies \\
\hline \multicolumn{5}{|l|}{ Budget: } \\
\hline Budget Planning & Valeria Day & day@iodp.tamu.edu & (979) $845-2580$ & USSSP/USSAC salary, science support, and travel funds for U.S. participants \\
\hline \multicolumn{5}{|c|}{ Information Services: Computers, Photography, Database: } \\
\hline Manager & David Becker & becker@iodp.tamu.edu & (979) 845-9324 & \\
\hline Supervisor of Information Technology Support & Philip Gates & gates@iodp.tamu.edu & (979) 845-9298 & \\
\hline Senior Imaging Specialist & John Beck & beck@iodp.tamu.edu & (979) 845-1183 & \\
\hline Data Librarian & Bo Slone & database@iodp.tamu.edu & (979) 845-3897 & To request data or core photographs from DSDP and ODP cruises \\
\hline \multicolumn{5}{|l|}{ Publications: } \\
\hline Manager & Angie Miller & amiller@iodp.tamu.edu & (979) 845-1196 & \\
\hline Publication Specialist & Kathy Phillips & phillips@iodp.tamu.edu & (979) 845-1191 & \\
\hline Senior Publications Coordinator & Gigi Delgado & delgado@iodp.tamu.edu & (979) 845-1909 & \\
\hline \multicolumn{5}{|l|}{ Travel: } \\
\hline Supervisor & Kathy Bass & bass@iodp.tamu.edu & (979) 845-0924 & \\
\hline \multicolumn{5}{|l|}{ JOIDES Resolution: } \\
\hline Staff Scientist & & JR_StaffSci@iodp.tamu.edu & & \\
\hline
\end{tabular}

Supervisor of Technical Support

Supervisor of Operational Support Supervisor of Materials Support

Manager

Staff Researcher

Budget:

Budget Planning

David Becker

formation

Data Librarian

Angie Miller

Gigi Delgado

Senior Publications Coordinato 
ODP SCIENCE SERVICES

ODP TECHNICAL Note 36

Table T3. Important Web addresses related to ODP.

\begin{tabular}{|c|c|}
\hline Ocean Drilling Program & www.oceandrilling.org/ \\
\hline What is ODP? & www-odp.tamu.edu \\
\hline JOIDES Resolution & www-odp.tamu.edu/resolutn.html \\
\hline International members & www-odp.tamu.edu/odpwww.htm \\
\hline JOI (program manager) & www.joiscience.org \\
\hline JOI/USSSP & www.usssp-iodp.org \\
\hline JOIDES & www-odp.tamu.edu/odpwww.htm \\
\hline Meetings/Panels & www.iodp.org/sas/ \\
\hline Operations structure & www.oceandrilling.org \\
\hline National Science Foundation & www.nsf.gov \\
\hline $\begin{array}{l}\text { ODP/LDEO } \\
\text { Logging Services } \\
\text { Site Surveys }\end{array}$ & $\begin{array}{l}\text { www.Ideo.columbia.edu/BRG/ODP/ } \\
\text { www.Ideo.columbia.edu/databank/ }\end{array}$ \\
\hline $\begin{array}{l}\text { ODP/TAMU } \\
\text { Drilling Services Department } \\
\text { Coring/Transit time estimator } \\
\text { Drilling operations }\end{array}$ & $\begin{array}{l}\text { www-odp.tamu.edu/dsd/ } \\
\text { www-odp.tamu.edu/dsd/drillest.html } \\
\text { www-odp.tamu.edu/public/onboarddrillops.html }\end{array}$ \\
\hline $\begin{array}{l}\text { Information Services Department } \\
\text { Shipboard computing } \\
\text { Network computer development/support } \\
\text { ODP application development } \\
\text { Database services } \\
\text { Janus database } \\
\text { Database overview } \\
\text { Predefined Janus queries } \\
\text { SQL queries/Paleontology dictionary } \\
\text { Data policy } \\
\text { Data librarian }\end{array}$ & $\begin{array}{l}\text { www-odp.tamu.edu/isg/ } \\
\text { www-odp.tamu.edu/isg/shipboard.html } \\
\text { www-odp.tamu.edu/isg/network.html } \\
\text { www-odp.tamu.edu/isg/appldev.html } \\
\text { www-odp.tamu.edu/isg/database.html } \\
\text { www-odp.tamu.edu/database/ } \\
\text { iodp.tamu.edu/janusweb/general/dbtable.cgi } \\
\text { iodp.tamu.edu/janusweb/links/links_all.shtml } \\
\text { iodp.tamu.edu/janusweb/paleo/paleo_dict.shtml } \\
\text { www-odp.tamu.edu/publications/policy.html } \\
\text { database@iodp.tamu.edu }\end{array}$ \\
\hline $\begin{array}{l}\text { Publications Department } \\
\text { Scientific Prospectus } \\
\text { Preliminary Reports } \\
\text { Initial Reports } \\
\text { Scientific Results } \\
\text { Author instructions } \\
\text { Sample Distribution, Data Distribution, and Publications Policy } \\
\text { Leg related publications (leg summaries, logging summary, citation list) }\end{array}$ & $\begin{array}{l}\text { www-odp.tamu.edu/publications/ } \\
\text { www-odp.tamu.edu/publications/pubs_sp.htm } \\
\text { www-odp.tamu.edu/publications/pubs_pr.htm } \\
\text { www-odp.tamu.edu/publications/ } \\
\text { www-odp.tamu.edu/publications/ } \\
\text { www-odp.tamu.edu/publications/CONTRIB.HTML } \\
\text { www-odp.tamu.edu/publications/policy.html } \\
\text { www-odp.tamu.edu/publications/pubs.htm }\end{array}$ \\
\hline $\begin{array}{l}\text { Public Information } \\
\text { News releases } \\
\text { For news media } \\
\text { Promotional materials } \\
\text { Ship tour } \\
\text { Life on the ship } \\
\text { Merchandise }\end{array}$ & $\begin{array}{l}\text { www-odp.tamu.edu/public/ } \\
\text { www.oceandrilling.org/Newsroom/News.html } \\
\text { www-odp.tamu.edu/public/ } \\
\text { www-odp.tamu.edu/public/promomat.html } \\
\text { www-odp.tamu.edu/public/onboard.html } \\
\text { www-odp.tamu.edu/public/life/index.html } \\
\text { www-odp.tamu.edu/public/shipsstores_catalog/stores_catalog.html }\end{array}$ \\
\hline $\begin{array}{l}\text { Science Services Department } \\
\text { Cruise application } \\
\text { Curation and repositories } \\
\text { Leg abstracts } \\
\text { ODP/DSDP site maps } \\
\text { ODP Micropaleontological Reference Centers } \\
\text { Sample request form } \\
\text { Scientific resources } \\
\text { Ship laboratories } \\
\text { Ship library } \\
\text { Technical Notes }\end{array}$ & $\begin{array}{l}\text { www-odp.tamu.edu/sciops/ } \\
\text { www.usssp-iodp.org/Science_Support/Sailing_Information/default.html } \\
\text { www-odp.tamu.edu/curation/ } \\
\text { www-odp.tamu.edu/publications/tnotes/fy0102/fy0102toc.html } \\
\text { www-odp.tamu.edu/sitemap/sitemap.html } \\
\text { www-odp.tamu.edu/mrc/ } \\
\text { www-odp.tamu.edu/curation/subsfrm.htm } \\
\text { www-odp.tamu.edu/sciops/resources.html } \\
\text { www-odp.tamu.edu/sciops/labs.html } \\
\text { www-odp.tamu.edu/sciops/ship_lib.html } \\
\text { www-odp.tamu.edu/publications/TECHREP.HTML }\end{array}$ \\
\hline $\begin{array}{l}\text { Administration Department } \\
\text { Travel/Meeting information } \\
\text { Employment } \\
\text { US/foreign per diem rates for cities visited most often } \\
\text { Port call information (i.e., port agent and hotel info) }\end{array}$ & $\begin{array}{l}\text { www-odp.tamu.edu/admin/ } \\
\text { www-odp.tamu.edu/admin/meetings.html } \\
\text { www-odp.tamu.edu/admin/odpjobs.html } \\
\text { www-odp.tamu.edu/admin/perdiem.html } \\
\text { www-odp.tamu.edu/admin/meetings.html }\end{array}$ \\
\hline Online Ship Tour & www-odp.tamu.edu/public/onboard.html \\
\hline Transocean & www.deepwater.com/ \\
\hline $\begin{array}{l}\text { Planning for post-2003 Ocean drilling } \\
\text { Integrated ODP (IODP) } \\
\text { IODP Planning Subcommittee } \\
\text { IWGSO } \\
\text { JAMSTEC }\end{array}$ & $\begin{array}{l}\text { www.iodp.org/ } \\
\text { www.iodp.org/ipsc/default.html } \\
\text { www.iodp.org/iwgso/iwg_sup.html } \\
\text { www.jamstec.go.jp/ }\end{array}$ \\
\hline
\end{tabular}

